\title{
Agronomic traits in common bean are influenced by infestation and coexistence with volunteer maize ${ }^{1}$
}

\author{
Adalin Cezar Moraes de Aguiar², Diecson Ruy Orsolin da Silva ${ }^{3}$, \\ Claudir José Basso ${ }^{3}$, Bruna Dal'Pizol Novello ${ }^{3}$, Álvaro André Alba da Silva ${ }^{3}$
}

\section{ABSTRACT}

Maize seeds lost during harvest may emerge and establish themselves during the cultivation of common bean, becoming a problematic weed in succession crops. This study aimed to evaluate the effect of the infestation level and interference period of volunteer maize on agronomic traits of common bean. The experiment was carried out in a randomized block design, with four replications, in a 2 x 8 factorial scheme consisting of two maize infestation levels (4 plants $\mathrm{m}^{-2}$ and 12 plants $\mathrm{m}^{-2}$ ) combined with eight coexistence periods between crop and weed $(0,7,14,21,28,35,42$ and 88 days after the emergence of the common bean). Variables related to the common bean vegetative growth (plant height, stem diameter, number of side branches and shoot dry matter) and to its grain production (number of pods per plant, grain yield and weight of 1,000 grains), as well as the period prior to interference, were assessed. The increase of the coexistence period and volunteer maize infestation level negatively affected the common bean growth and grain yield. The densities with 4 plants $\mathrm{m}^{-2}$ and 12 plants $\mathrm{m}^{-2}$ of volunteer maize reduced the common bean grain yield by $60 \%$ and $84 \%$, respectively; while the periods prior to interference between crop and weed, for the respective infestation levels, were 15 and 8 days after the common bean emergence. In addition, the volunteer maize reduces the period prior to interference to very low values, indicating the need to anticipate the control of this weed.

KEYWORDS: Phaseolus vulgaris, Zea mays, volunteer plants, weeds.

\section{INTRODUCTION}

Among the factors responsible for a low crop yield, the interference imposed by weeds stands out. When not controlled, weeds compete for essential resources of the environment, such as water, light and nutrients, in addition to hindering harvest operations

\section{RESUMO}

Características agronômicas em feijoeiro são influenciadas por infestação e convivência com milho voluntário

Sementes de milho perdidas durante a colheita podem emergir e se estabelecer durante o cultivo do feijão-comum, tornando-se planta invasora problemática em cultivos de sucessão. Objetivou-se avaliar o efeito do nível de infestação e do período de interferência de milho voluntário sobre caracteres agronômicos de feijoeiro. O experimento foi conduzido em blocos casualizados, com quatro repetições, em esquema fatorial 2 x 8 , sendo dois níveis de infestação do milho (4 plantas $\mathrm{m}^{-2}$ e 12 plantas $\mathrm{m}^{-2}$ ) combinados com oito períodos de convivência entre cultura e planta invasora $(0,7,14,21,28,35,42$ e 88 dias após a emergência do feijoeiro). Variáveis relacionadas ao crescimento vegetativo do feijoeiro (altura de planta, diâmetro de caule, número de ramos laterais e massa seca da parte aérea) e à sua produção de grãos (número de vagens por planta, produtividade e massa de mil grãos), além do período prévio à interferência, foram avaliadas. O aumento do período de convivência e do nível de infestação do milho voluntário afetou negativamente o crescimento e o rendimento de grãos do feijoeiro. As densidades com 4 plantas $\mathrm{m}^{-2} \mathrm{e} 12$ plantas $\mathrm{m}^{-2}$ de milho voluntário reduziram o rendimento do feijoeiro em $60 \%$ e $84 \%$, respectivamente; enquanto os períodos prévios à interferência entre cultura e planta invasora, para os respectivos níveis de infestação, foram de 15 e 8 dias após a emergência do feijoeiro. Além disso, o milho voluntário reduz o período anterior à interferência a valores muito baixos, indicando a necessidade de antecipação do controle dessa planta invasora.

PALAVRAS-CHAVE: Phaseolus vulgaris, Zea mays, plantas voluntárias, plantas daninhas.

and reducing the quality of products. Furthermore, these plants may serve as intermediate hosts for insects, nematodes and disease-causing agents (Silva et al. 2008).

The degree of interference between weeds and crops can be changed as a function of the period in which the plant community is disputing a particular

1. Received: June 24, 2019. Accepted: Feb. 05, 2020. Published: Apr. 22, 2020. DOI: 10.1590/1983-40632020v5059098.

2. Universidade Federal de Viçosa, Departamento de Fitotecnia, Viçosa, MG, Brasil.

E-mail/ORCID: adalin-cezar@hotmail.com/0000-0003-1138-8197.

3. Universidade Federal de Santa Maria, Departamento de Ciências Agronômicas e Ambientais, Frederico Westphalen, RS,

Brasil.E-mail/ORCID: diecsonros@hotmail.com/0000-0002-0354-7744, claudirbasso@gmail.com/0000-0002-3013-5702, brunadalpizoln@outlook.com/0000-0002-1099-6900,alvaroalba1@outlook.com/0000-0002-3854-1449. 
resource (Silva et al. 2009). In this context, infestation level and coexistence period are important aspects that affect the interference of the infesting community on the crop. This coexistence between weed and crop causes changes in the plant growth, such as changes in the number of leaves, leaf area, emission of branches and dry matter of cultivated plants, thus compromising the development of reproductive structures and grain yield (Lamego et al. 2004, Silva et al. 2008, Freitas et al. 2009, Silva et al. 2009, Aguiar et al. 2018).

Since common bean is cultivated at different times of the year, in various cultivation systems and under the most varied edaphoclimatic conditions, it may suffer interference from several weed species (Scholten et al. 2011). In a second-crop cultivation system, common bean becomes an option in the succession system after maize in southern Brazil, with a cultivated area of $284 \times 10^{3}$ ha (Conab 2016). In this production system, maize grains lost during harvest may emerge and establish themselves during the cultivation of common bean, thus becoming a problematic weed under these conditions (Marquardt et al. 2012, Alms et al. 2016, Sbatella et al. 2016).

Losses caused during the maize harvest may be influenced by many factors, such as plant spacing and density, weed occurrence, delay in harvest, inadequate moisture in grains and straw, lack of monitoring and poor regulation, in addition to operational failures (Oliveira et al. 2014). The acceptable value of harvest loss for maize is around 1.5 bags ha $\mathrm{h}^{-1}$. However, Venegas et al. (2012) found losses that ranged from 0.29 bags ha $^{-1}$ to 11 bags ha $^{-1}$ just varying the speed of the cylinder. As a result, the density of volunteer maize in succession cultivation depends on several factors related to good management practices at the time of the maize harvest.

There are reports of volunteer maize competition with various crops, such as soybean [Glycine max (L.) Merr.], cultivated maize itself (Zea mays), beet (Beta vulgaris L.) and cotton (Gossypium hirsutum L.) (Thomas et al. 2007, Kniss et al. 2012, Marquardt et al. 2012, Alms et al. 2016, Aguiar et al. 2018). However, information about the effects of volunteer maize on the bean crop is still scarce and essentially related to the coexistence period of this weed with the crop.

Among the three interference periods designated by Pitelli (1985), the period prior to interference stands out, from the sowing or planting of a certain crop in which it can live with weed plants without reductions in yield. The identification of the period prior to interference in crops is essential to determine the appropriate control schedule and the effective use of herbicides. Thus, the knowledge of the period before the interference of volunteer maize in the common bean crop is useful for the development of better management strategies for this weed, indicating the ideal time interval for control in this cultivation system (Otto et al. 2009, Silva et al. 2013).

Thus, this study aimed to evaluate the effect of volunteer maize infestation levels on agronomic traits of common bean, in addition to determine the period prior to interference between weed and crop.

\section{MATERIAL AND METHODS}

The study was carried out under field conditions, at the experimental area of the Universidade Federal de Santa Maria, in Frederico Westphalen, Rio Grande do Sul state, Brasil $\left(27^{\circ} 23^{\prime} 20^{\prime \prime}\right.$ S and $\left.53^{\circ} 25^{\prime} 41^{\prime \prime} \mathrm{W}\right)$, during the 2016/2017 growing season. According to Köppen, the climate of the region is $\mathrm{Cfa}$, with an average annual temperature of $19.1{ }^{\circ} \mathrm{C}$ (maximum of $38{ }^{\circ} \mathrm{C}$ and minimum of $0{ }^{\circ} \mathrm{C}$ ). The soil of the area is classified as a typic Oxisol (3.2\% of organic matter, $60 \%$ of clay, $\mathrm{pH}$ of 6.2 and phosphorus and potassium contents of $4.5 \mathrm{mg} \mathrm{dm}^{-3}$ and $120.5 \mathrm{mg} \mathrm{dm}^{-3}$, respectively). Temperature and rainfall data were collected during the experiment.

The experiment was installed in a randomized complete block design, with four replications. The treatments were arranged in a $2 \times 8$ factorial scheme, being two volunteer maize infestation levels [low (4 plants $\mathrm{m}^{-2}$ ) and high $\left(12\right.$ plants $\left.\mathrm{m}^{-2}\right)$ ] and eight coexistence periods between weed and crop $(0,7$, $14,21,28,35,42$ and 88 days after the emergence of the common bean).

The experimental area was prepared with desiccation, using glyphosate $\left(1,080 \mathrm{~g}\right.$ a.i. ha $\left.^{-1}\right)$. After the desiccation, the common bean 'IPR Uirapuru' cultivar was sown at a density of 15 seeds $\mathrm{m}^{-1}$, spaced at $45 \mathrm{~cm}$ between rows. The experimental units consisted of $5.00 \mathrm{~m} \times 2.25 \mathrm{~m}$, comprising five rows of bean with the seeds of volunteer maize distributed randomly between rows. For the bean sowing, a tractor seed drill was used, while, for the maize sowing, a manual seeder was used. The emergence of both crops occurred on September 26, 2016.

For fertilization of the common bean crop, $12.5 \mathrm{~kg} \mathrm{ha}^{-1}$ of $\mathrm{N}, 62.5 \mathrm{~kg} \mathrm{ha}^{-1}$ of $\mathrm{P}_{2} \mathrm{O}_{5}$ and $37.5 \mathrm{~kg} \mathrm{ha}^{-1}$ 
of $\mathrm{K}_{2} \mathrm{O}$ were used, in addition to $45 \mathrm{~kg} \mathrm{ha}^{-1}$ of $\mathrm{N}$ covered at the stage V3. Other weeds emerging in the area during the trial, except for the volunteer maize, were controlled by manual weeding. For the management of pest insects, the insecticide zetacypermethrin (52.5 g a.i. ha $\left.{ }^{-1}\right)$ was used, while diseases were managed with the fungicides trifloxystrobin + prothioconazole $\left(70.0+60.0 \mathrm{~g}\right.$ a.i. ha $\left.{ }^{-1}\right)$, under crop monitoring. All applications were carried out with the aid of a $20-\mathrm{L}$ costal sprayer, equipped with an application bar with four XR 110.02 fan tips, $0.5 \mathrm{~m}$ apart, with a spray volume of $150 \mathrm{~L} \mathrm{ha}^{-1}$.

At the full flowering stage, the shoot dry matter of common bean plants was measured by cutting and collecting $1.0 \mathrm{~m}^{2}$ from the useful area of each plot. This material was packed in properly identified paper bags and deposited in an oven at a constant temperature of $60^{\circ} \mathrm{C}$, until a constant dry weight was reached. The shoot dry matter was weighed on a precision scale and expressed in $\mathrm{kg} \mathrm{ha}^{-1}$.

At pre-harvest, the plant height $(\mathrm{cm})$, stem diameter $(\mathrm{mm})$, number of side branches and number of pods per common bean were evaluated, randomly averaging seven plants from the useful area of each plot. Harvest was carried out on December 23, 2016, at 88 days after the emergence of the common bean. The grain yield was then evaluated, manually harvesting three central rows from the 3 -m plots. The material was processed and the grains were cleaned and weighed. Subsequently, the water content of each sample was determined and corrected to $13 \%$. The grain yield was expressed in $\mathrm{kg} \mathrm{ha}^{-1}$. The measurement of weight of 1,000 grains (g) was also carried out, for which eight samples of 100 seeds were weighed on a precision scale and corrected for the water content.

The data were submitted to analysis of variance by the $\mathrm{F}$ test at $5 \%$ of significance and, when significant, a regression analysis was performed. To determine the period prior to interference, an arbitrary level of acceptable grain yield loss was adopted (5\%), which was subtracted from the bean yield where the plants would develop free of weeds (Knezevic \& Datta 2015). The data were adjusted to the logistic model with the best fit, using the SigmaPlot $^{\circledR} 14.0$ software (Systat 2019).

\section{RESULTS AND DISCUSSION}

The temperature conditions were adequate for a good crop development throughout the cycle. As for the rainfall index, there was only a small deficit between November 11th and 20th. However, a water supplementation of $20 \mathrm{~mm}$ was made, enough to complement the low rainfall recorded and provide sufficient water conditions for a good development of the crop. Therefore, the climatic conditions for the period in which the crop remained in the field can be considered satisfactory for its good development (Figure 1).

The height of the common bean plants increased linearly with the increase in the coexistence period with maize plants (Figure 2A). However, it did not differ between the two maize infestation levels (Figure 3A). When competing for light, plants tend to develop more in height, in order to obtain an advantage in capturing this resource from the environment, a result attributed to changes in the quality and intensity of the incident light on plants (Ballare \& Casal 2000, Rajcan \& Swanton 2001). In theory, plants of a given crop will be taller the greater the competition imposed by weeds. In some cases, this will occur even if the competition has not reached critical levels yet (Silva et al. 2009).

Shading by weeds affects the incident wavelength on the crop, increasing the incidence of distant red light, resulting in a greater allocation of resources for investment in shoot growth. This greater allocation in the shoot may also affect the development of the root system, compromising the dispute for soil resources (Rajan \& Swanton 2001).

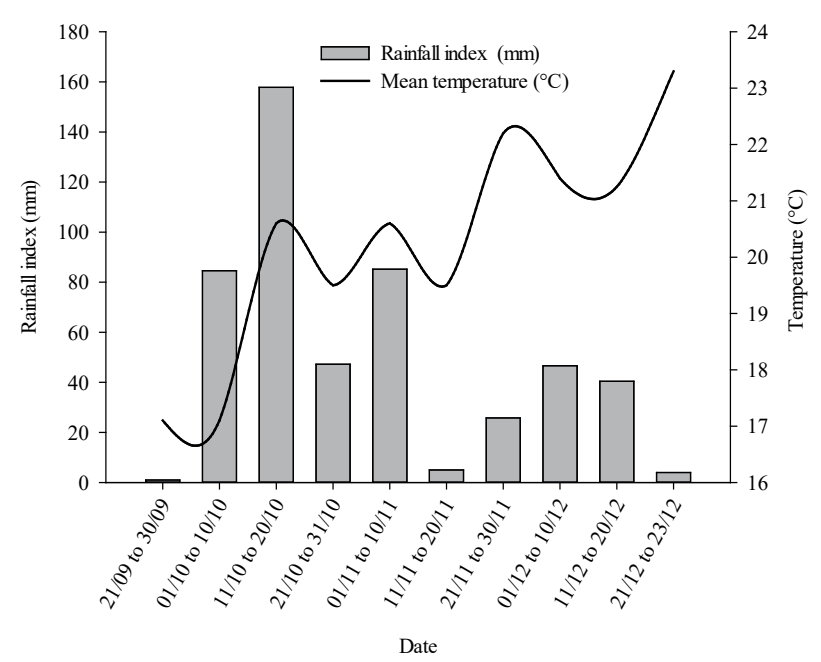

Figure 1. Rainfall index $(\mathrm{mm})$ and average air temperature $\left({ }^{\circ} \mathrm{C}\right)$, mean of every ten days, from sowing to harvest of the common bean crop. 

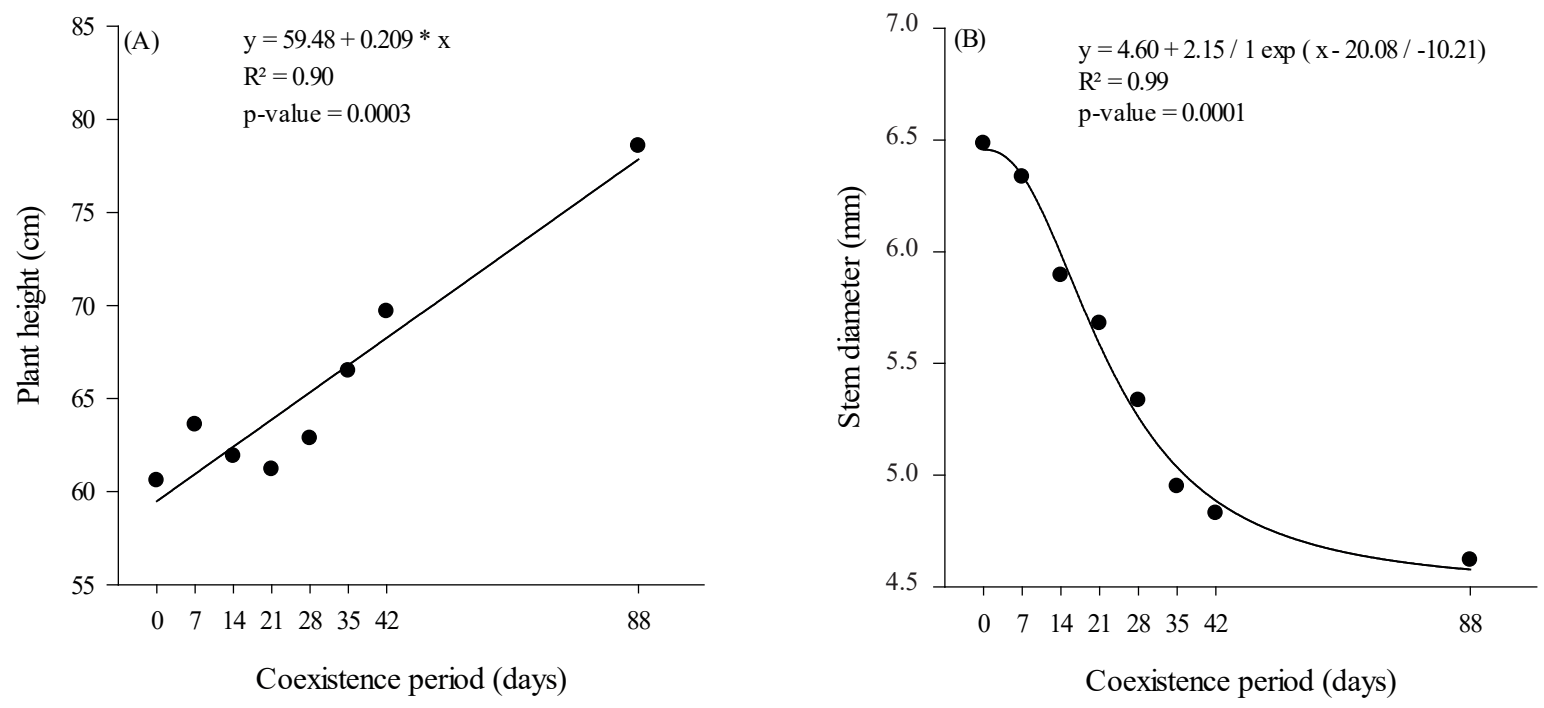

Figure 2. Plant height (A) and stem diameter (B) of common bean, as a function of the coexistence period with volunteer maize.

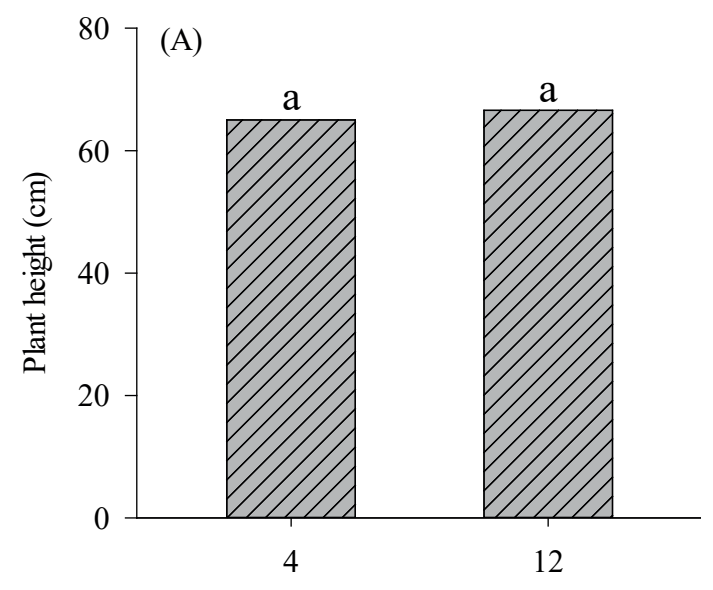

Volunteer maize infestation levels (plants $\mathrm{m}^{-2}$ )

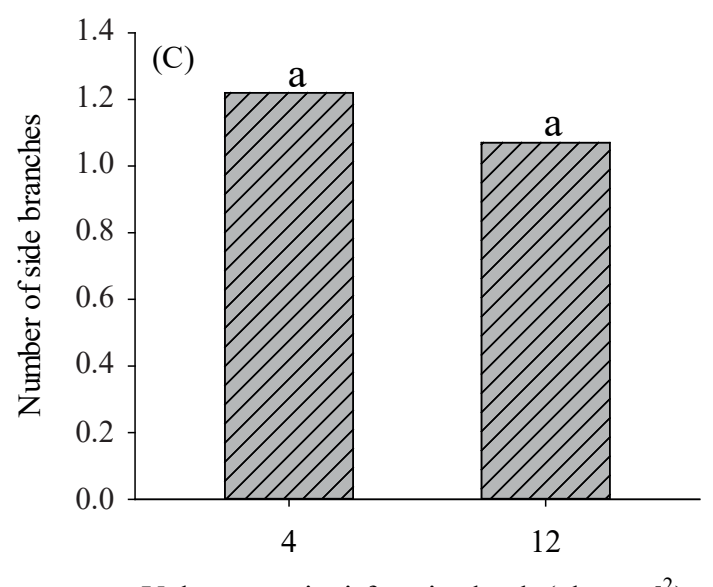

Volunteer maize infestation levels (plants $\mathrm{m}^{-2}$ )

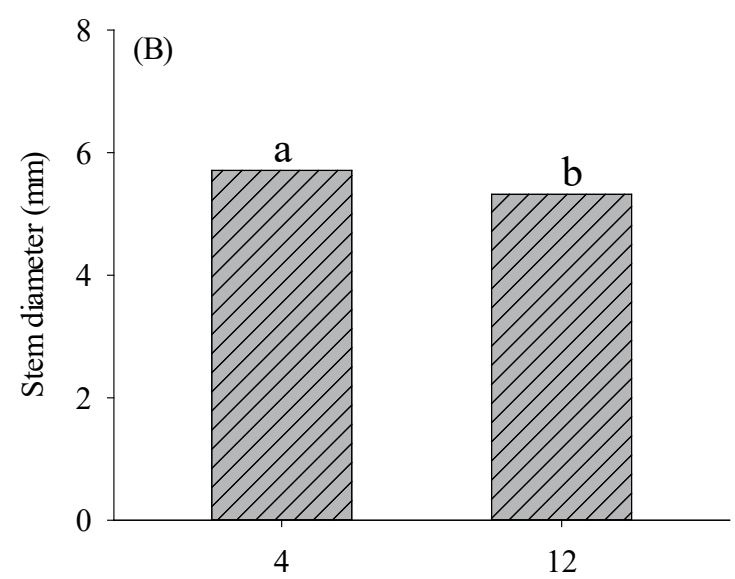

Volunteer maize infestation levels (plants $\mathrm{m}^{-2}$ )

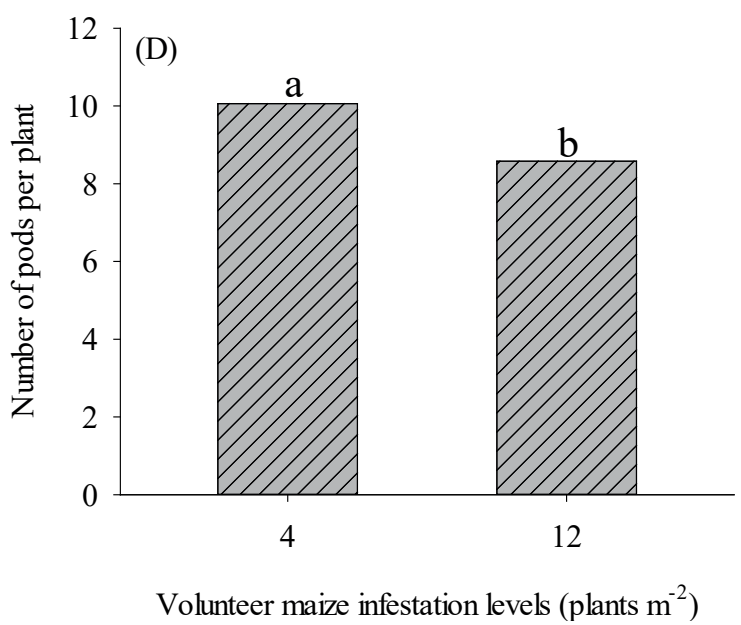

Figure 3. Plant height (A), stem diameter (B), number of side branches (C) and number of pods per plant (D) of common bean, as a function of volunteer maize infestation levels. 
The stem diameter of common bean plants decreased with the increase in the coexistence period with volunteer maize plants (Figure 2B). A greater reduction for stem diameter of the common bean at the higher maize infestation $\left(12\right.$ plants $\left.\mathrm{m}^{-2}\right)$ was observed, reaching $7.0 \%$, when compared to the lower infestation with 4 plants $\mathrm{m}^{-2}$ (Figure 3B).

Changes in the stem diameter are linked to plant growth in height. The elongation effect of the plants affects the reduction in stem diameter in the same direction, since weeds are able to induce changes in the quality of the light predominant in the lower part of the canopy, causing a delay in the diameter development of plants (Crotser et al. 2003).

The increase in the coexistence period drastically reduced the emission of branches of common bean plants. Likewise, the production of pods by common bean plants was negatively affected in the presence of volunteer maize (Figure 4). There was no difference between the maize infestation levels for the emission of branches of common bean plants. On the other hand, competition with high infestation reduced the number of pods by $17.2 \%$, when comparing the lower infestation levels (Figures 3C and 3D).

The reduction in the number of stem branches occurs due to the competition for light, which reduces the availability of photoassimilates responsible for the growth of the branches that are preferably intended for growth in height of the main stem (Martins et al. 1999). The reduction in the number of branches may compromise reproductive structures and, consequently, grain yield (Lamego et al. 2004). Thus, there was a reduction in the number of legumes per plant with the increase in competition periods with volunteer maize (Figure 4A).

The reduction in the number of pods may be related to the number of side branches (i.e., the smaller number of branches provides a smaller number of buds), reducing the number of flowers (Machado et al. 2015). Freitas et al. (2009) reports that the explanation for the reduction in the number of pods may be related to the lower inflorescence emission and flower abortion caused by the competition imposed by weeds for resources of the environment.

The dry matter production of common bean plants reached close to $4,000 \mathrm{~kg} \mathrm{ha}^{-1}$ in the absence of competition, indicating a good crop development. However, it was significantly reduced with the increase in the coexistence periods with volunteer maize, reaching values close to $50 \%$. This impact may be related to the high shading caused by maize plants, leading to a direct competition for light due to their greater height (Figure 5A). Another important factor that must be considered is that common bean fits the class of crops with less competitiveness with weeds, due to a slow initial growth and low canopy cover (Manabe et al. 2015).
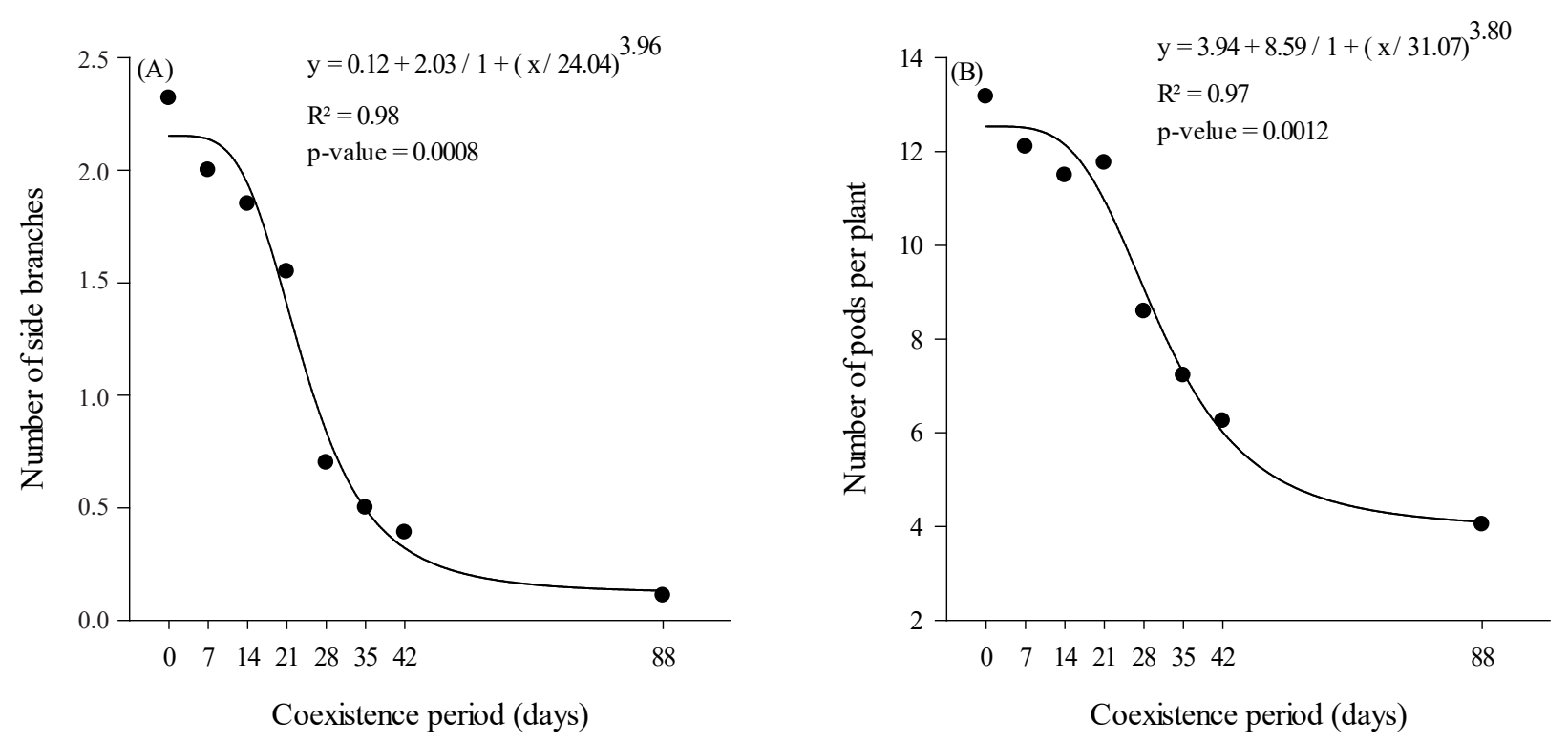

Figure 4. Number of side branches (A) and number of pods per plant (B) of common bean, as a function of the coexistence period with volunteer maize. 

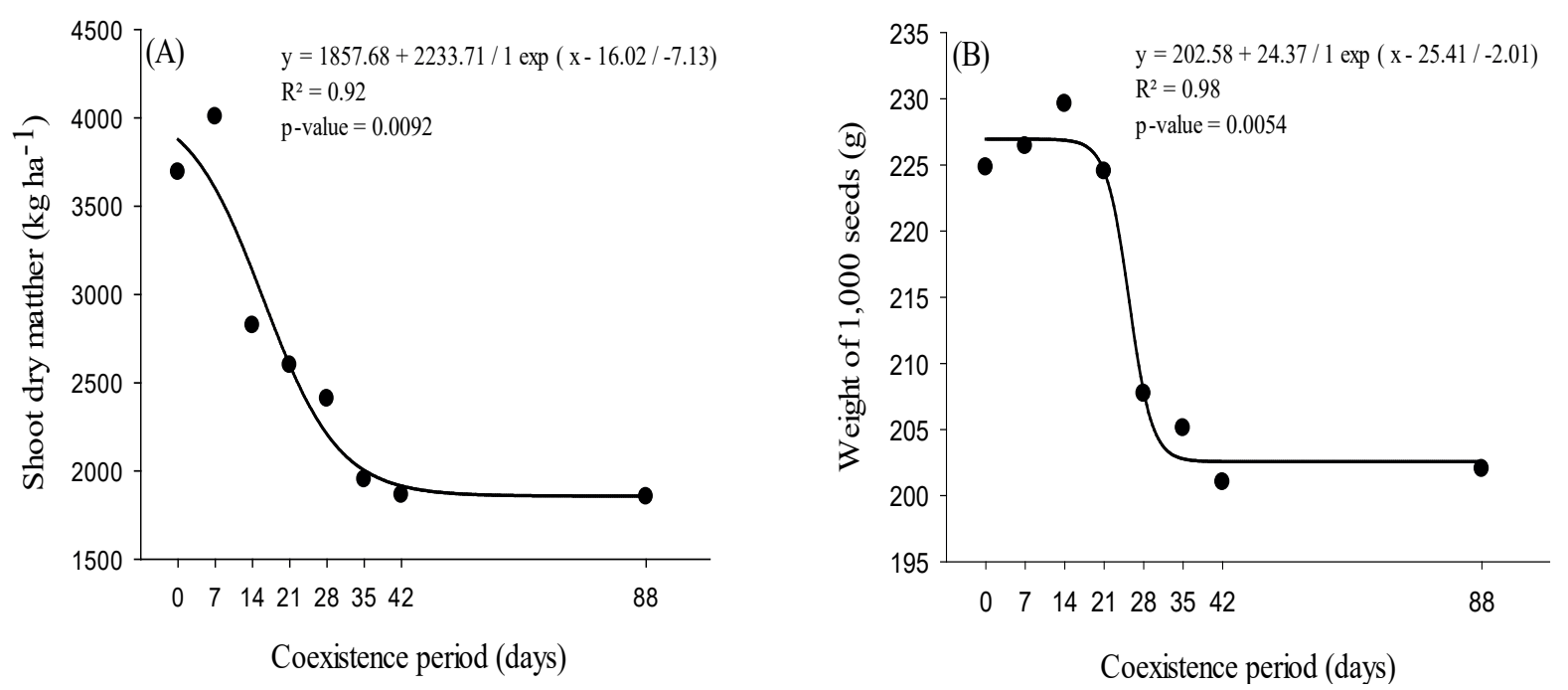

Figure 5. Shoot dry matter (A) and weight of 1,000 seeds (B) of common bean, as a function of the coexistence period with volunteer maize.

The increase in the volunteer maize infestation from 4 plants $\mathrm{m}^{-2}$ to 12 plants $\mathrm{m}^{-2}$ reduced the dry matter production from $2,893 \mathrm{~kg} \mathrm{ha}^{-1}$ to $2,407 \mathrm{~kg} \mathrm{ha}^{-1}$, respectively (Figure 6A). Maize shows advantages for having a canopy architecture different from common bean giving its greater competitive capacity, reducing the quality of light in neighboring plants. In addition, maize is $\mathrm{C}_{4}$ plant and has a well-developed root system, causing a high interference when in competition, a characteristic that gives a highly competitive ability when compared to other weeds (Marquardt et al. 2012, Caratti et al. 2016).

The increase in the coexistence period with volunteer maize also reduced the weight of 1,000 seeds of common bean (Figure 5B). However, there was no difference in comparison to the infestation levels (Figure 6B). Freitas et al. (2009), in a study with cowpea, did not observe a significant difference for the same variable under the interference of weeds, in contrast to the control absent of competition. In contrast, the competition imposed by weeds on chickpea reduced the mean values for this trait (Teixeira et al. 2017).

Bean yield was reduced with the increase in the coexistence period with volunteer maize, regardless of the imposed infestation level (Figure 7). The competition of 4 volunteer maize plants $\mathrm{m}^{-2}$ throughout the crop cycle reduced the grain yield by $60 \%$, while, at the highest maize density, the loss was of $84 \%$. These values are similar to those observed by Soltani et al. (2018), who found losses for the bean crop in Canada and in the USA close to $70 \%$, in the absence of weed management tactics. Alms et al. (2016), in a study about the interference of volunteer maize on soybean crop, verified a maximum grain yield loss of $71 \%$, due to competition. In relation to the competition of weeds such as Euphorbia heterophylla with common bean, losses are lower, with a maximum asymptote of $54 \%$ (Machado et al. 2015). This shows the high interference capacity of the volunteer maize.

There was no significant interaction between the factors. However, the increase in the weed infestation level reduced the grain yield of common bean by $24 \%$ (Figure 6C). The greatest effect in reducing the number of pods per plant, weight of 1,000 seeds and yield of bean grains is due to the high infestation of voluntary maize ( 12 plants $\mathrm{m}^{-2}$ ) and also by the high competitive capacity of maize. At high densities, competition is intensified, so that the highest and most developed weeds (in this case maize) become dominant, suppressing the common bean plants. Working with interference from volunteer maize in the bean crop, Silva et al. (2019) found maximum losses close to $70 \%$. The authors list this high loss in grain yield due to the aggressiveness of volunteer maize when in competition. This aggressiveness is associated with the high plant canopy development, which causes shading on the bean plants. Another factor is caused by the fact that maize has a highly developed root system, causing a high absorption of nutrients and water in the soil. 

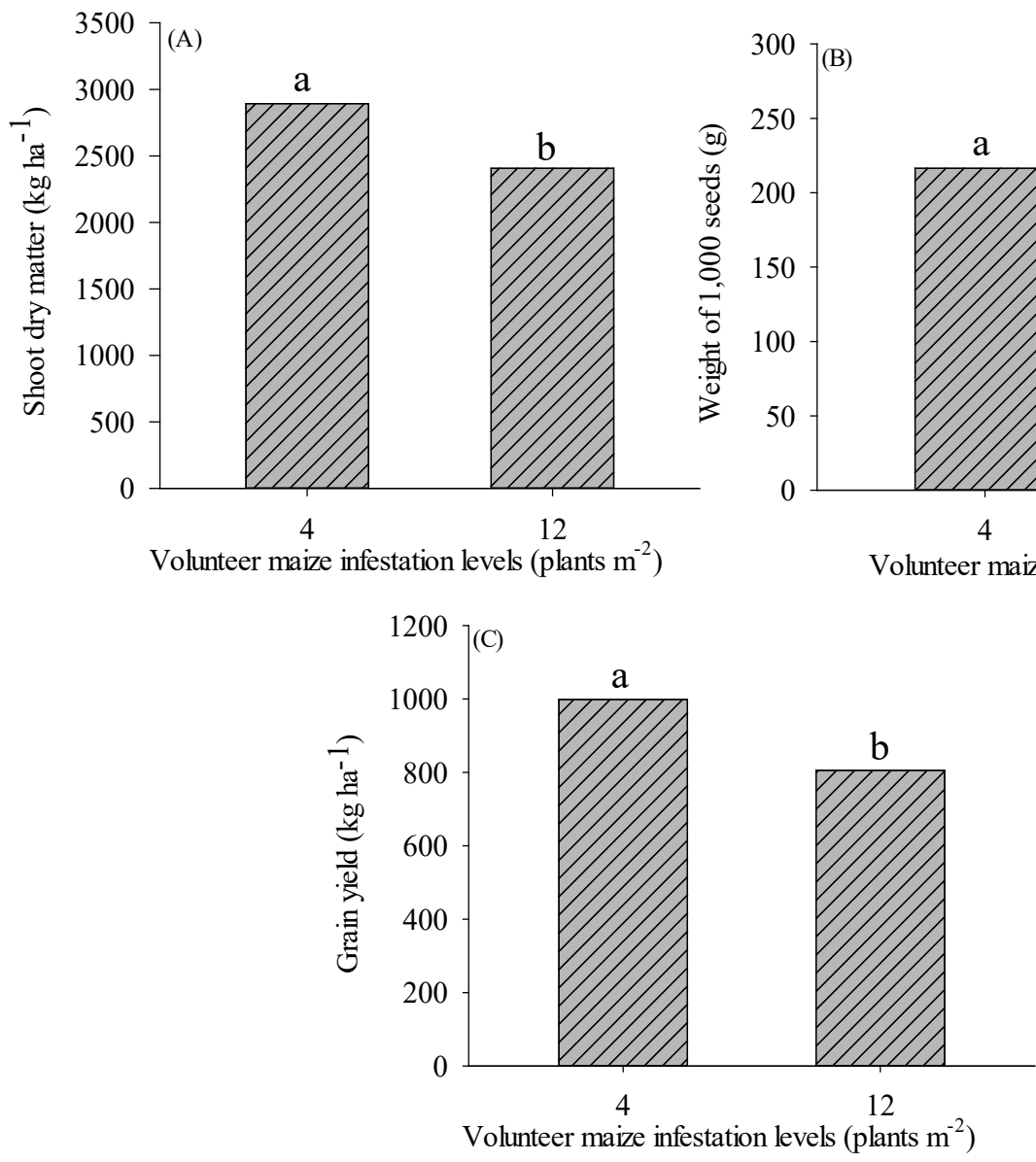

Figure 6. Shoot dry matter (A), weight of 1,000 seeds (B) and grain yield (C) of common bean, as a function of volunteer maize infestation levels.
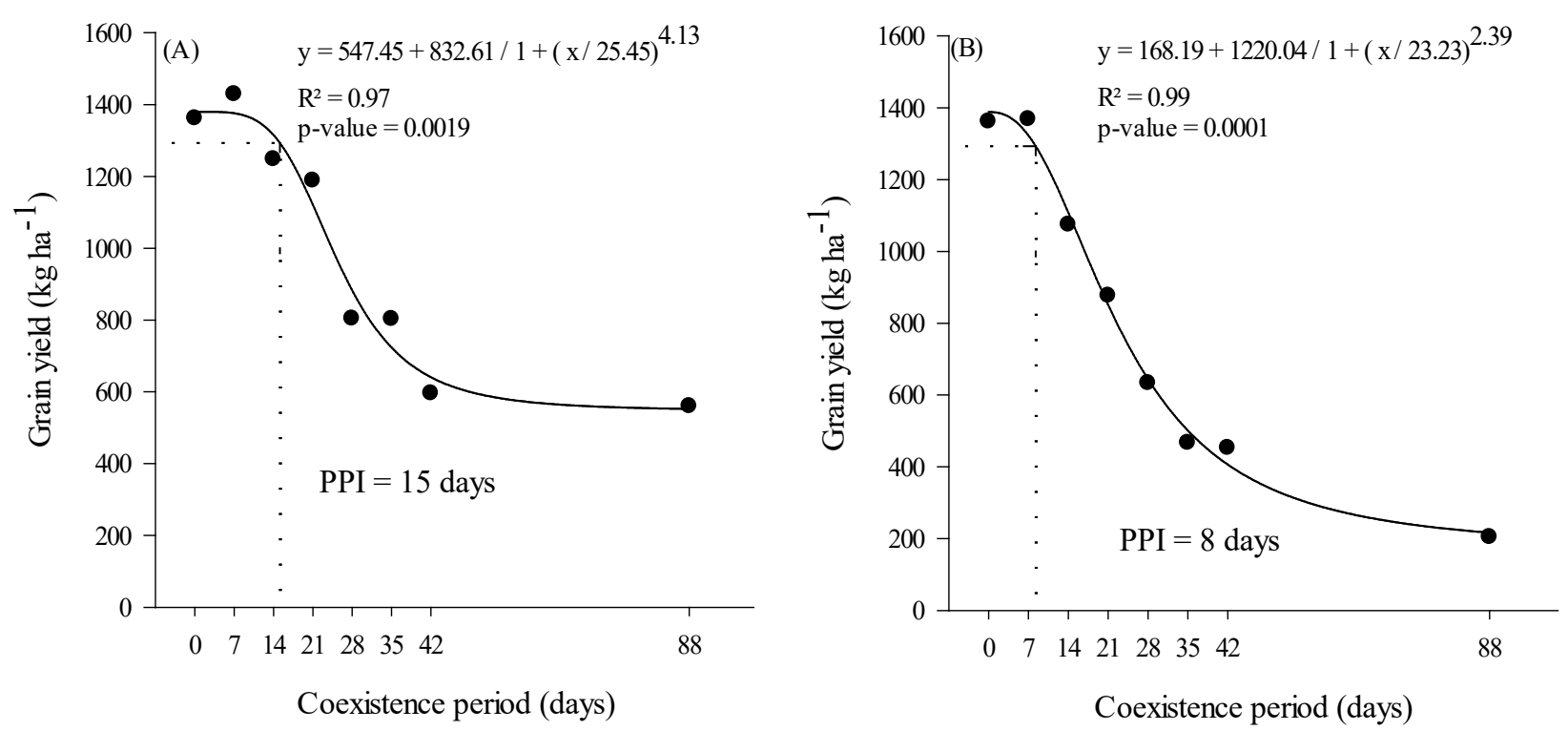

Figure 7. Grain yield of common bean cultivated under low (A) and high (B) density of volunteer maize (4 plants $\mathrm{m}^{-2}$ and 12 plants $\mathrm{m}^{-2}$, respectively), as a function of the coexistence period between weed and crop. 
The curves shown in Figure 7 represent the grain yield obtained when the crop remained for increasing coexistence periods with volunteer maize weeds, what allows the determination of the period prior to interference, which is understood as the coexistence with weeds for a certain period, which does not negatively interfere with crop grain yield (Brighenti et al. 2004). For both the volunteer maize densities, this prior period was included in the initial development stage of common bean, at 15 and 8 days after the emergence, respectively for the low and high infestation levels of volunteer maize.

In a study about weed interference on cowpea, Freitas et al. (2009) found that the crop started to be negatively affected by the coexistence with weeds from 11 days after the emergence. In common bean, Scholten et al. (2011) observed that the crop was able to coexist with some weeds (Acanthospermum hispidum, Arachis hypogaea, Cenchrus echinatus, Portulaca oleracea and Raphanus raphanistrum) for up to 27, 23, 19 and 13 days after the emergence, for the respective combinations between sowing densities (10 plants $\mathrm{m}^{-2}$ and 15 plants $\left.\mathrm{m}^{-2}\right)$ and row spacings $(0.45 \mathrm{~m}$ and $0.60 \mathrm{~m})$.

The period prior to common bean interference is short when competing with weeds, and can be further reduced when coexisting with highly aggressive plants, such as volunteer maize. In this case, the reduced period prior to interference can be associated with the high aggressiveness of maize when in competition and the high susceptibility of common bean, due to the characteristics of low plant height and slow initial growth.

The use of strategies to reduce infestation by volunteer maize, such as reducing crop losses, is feasible for the common bean crop. If it is not possible, it will be necessary to anticipate the decision making in relation to the control of this weed, to avoid high grain yield losses of the crop.

\section{CONCLUSION}

The infestation level of volunteer maize and coexistence period between this weed and common bean crop negatively influence important agronomic traits of the crop, such as plant height, stem diameter, shoot dry matter, grain yield and its components. The increase in the density of volunteer maize reduces the period prior to interference between weed and crop to very low values, indicating the need to anticipate the control of this weed in common bean crops.

\section{ACKNOWLEDGMENTS}

The present research was supported by the Coordenação de Aperfeiçoamento de Pessoal de Nível Superior (Capes, Ministério da Educação, Brasil; Financing Code 001).

\section{REFERENCES}

AGUIAR, A. C. M.; BASSO, C. J.; MURARO, D. S.; PANSERA, E.; SILVA, D. R. O. Interference and economic threshold level of volunteer corn in soybean. Planta Daninha, v. 36, e018178310, 2018.

ALMS, J.; MOECHNIG, M.; VOS, D.; CLAY, S. A. Yield loss and management of volunteer corn in soybean. Weed Technology, v. 30, n. 1, p. 254-262, 2016.

BALLARE, C. L.; CASAL, J. J. Light signals perceived by crop and weed plants. Fields Crops Research, v. 67, n. 2, p. 149-160, 2000.

BRIGHENTI, A. M.; CASTRO, C.; OLIVEIRA JUNIOR, R. S.; SCAPIM, C. A.; VOLL, E.; GAZZIERO, D. L. P. Períodos de interferência de plantas daninhas na cultura do girassol. Planta Daninha, v. 22, n. 2, p. 251-257, 2004.

CARATTI, F. C.; LAMEGO, F. P.; SILVA, J. D. G.; GARCIA, J. R.; AGOSTINETTO, D. Partitioning of competition for resources between soybean and corn as competitor Plant. Planta Daninha, v. 34, n. 4, p. 657-665, 2016.

COMPANHIA NACIONAL DE ABASTECIMENTO (Conab). Acompanhamento da safra brasileira de grãos: safra 2015/16: $4^{\circ}$ levantamento. Brasília, DF: Conab, 2016.

CROTSER, M. P.; WITT, W. W.; SPOMER, L. A. Neutral density shading and far-red radiation influence black nightshade (Solanum nigrum) and eastern black nightshade (Solanum ptycanthum) growth. Weed Science, v. 51, n. 2, p. 208-213, 2003.

FREITAS, F. C. L.; MEDEIROS, V. F. L. P.; GRANGEIRO, L. C.; SILVA, M. G. O.; NASCIMENTO, P. G. M. L.; NUNES, G. H. Interferência de plantas daninhas na cultura do feijão-caupi. Planta Daninha, v. 27, n. 2, p. 241-247, 2009.

KNEZEVIC, S. Z.; DATTA, A. The critical period for weed control: revisiting data analysis. Weed Science, v. 63, n. 1, p. 188-202, 2015.

KNISS, A. R.; SBATELLA, G. M.; WILSON, R. G. Volunteer glyphosate resistant corn interference and control in glyphosate resistant sugar beet. Weed Technology, v. 26, n. 2, p. 348-355, 2012.

LAMEGO, F. P.; FLECK, N. G.; BIANCHI, M. A.; SCHAEDLER, C. E. Tolerância à interferência de plantas 
competidoras e habilidade de supressão por genótipos de soja: II. Respostas de variáveis de produtividade. Planta Daninha, v. 22, n. 4, p. 491-98, 2004.

MACHADO, A. B.; TREZZI, M. M. I.; VIDAL, R. A.; PATEL, F.; CIESLIK, L. F.; DEBASTIANI, F. Rendimento de grãos de feijão e nível de dano econômico sob dois períodos de competição com Euphorbia heterophylla. Planta Daninha, v. 33, n. 1, p. 41-48, 2015.

MANABE, P. M. S.; MATOS, C. C.; FERREIRA, E. A.; SILVA, A. F.; SILVA, A. A.; SEDIYAMA, T.; MANABE, A.; ROCHA, P. R. R.; SILVA, C. T. Efeito da competição de plantas daninhas na cultura do feijoeiro. Bioscience Journal, v. 31, n. 2, p. 333-343, 2015.

MARQUARDT, P. T.; KRUPDE, C.; JOHNSON, W. G. Competition of transgenic volunteer corn with soybean and the effect on western corn rootworm emergence. Weed Science, v. 60, n. 2, p. 193-198, 2012.

MARTINS, M. C.; CÂMARA, G. M. S.; PEIXOTO, C. P.; MARCHIORI, L. F. S.; LEONARDO, V.; MATTIAZZI, P. Épocas de semeadura, densidades de plantas e desempenho vegetativo de cultivares de soja. Scientia Agricola, v. 56, n. 4, p. 851-858, 1999.

OLIVEIRA, T. C.; FIGUEIREDO, N. Z.; FAVARE, H. G.; TROUI, J. G.; SILVA, R. P. Perdas quantitativas na colheita mecanizada de milho safrinha na região norte de Mato Grosso. Agrarian Academy, v. 1, n. 2, p. 141-149, 2014.

OTTO, S.; MASIN, R.; CASARI, G.; ZANIN, G. Weedcorn competition on parameters in late-winter sowing in northern Italy. Weed Science, v. 57, n. 2, p. 194-201, 2009.

PITELLI, R. A. Interferência de plantas daninhas em culturas agrícolas. Informativo Agropecuário, v. 11, n. 1, p. 16-27, 1985.

RAJAN, I.; SWANTON, C. L. Understanding maize-weed competition, light quality and the whole plant. Field Crops Research, v. 71, n. 2, p. 139-150, 2001.

SBATELLA, G. M.; KNISS, A. R.; OMONDI, E. C.; WILSON, R. G. Volunteer corn (Zea mays) interference in dry edible bean (Phaseolus vulgaris). Weed Technology, v. 30, n. 4, p. 937-342, 2016.

SCHOLTEN, R.; PARREIRA, M. C.; ALVES, P. L. C. A. Período anterior à interferência das plantas daninhas para a cultivar de feijoeiro 'Rubi' em função do espaçamento e da densidade de semeadura. Acta Scientiarum Agronomy, v. 33, n. 2, p. 313-320, 2011.
SILVA, A. F.; CONCENÇO, G.; ASPIAZÚ, I.; FERREIRA, E. A.; GALON, L.; COELHO, A. T. C. P.; SILVA, A. A.; FERREIRA, F. A. I. Interferência de plantas daninhas em diferentes densidades no crescimento da soja. Planta Daninha, v. 27, n. 1, p. 75-84, 2009.

SILVA, A. F.; FERREIRA, E. A.; CONCENÇO, G.; FERREIRA, F. A.; ASPIAZU, I.; GALON, L.; SEDIYAMA, T.; SILVA, A. A. Densidades de plantas daninhas e épocas de controle sobre os componentes de produção da soja. Planta Daninha, v. 26, n. 1, p. 65-71, 2008.

SILVA, D. R. O.; AGUIAR, A. C. M. de; BASSO, C. J.; BORELLA, J.; GHELLER, D. P.; NOVELLO, B. D. P.; RIEDER, E. Perda de rendimento de feijão em resposta ao milho voluntário. Revista Brasileira de Ciências Agrárias (Agrária), v. 14, n. 2, e5636, 2019.

SILVA, R. R. D.; REIS, M. R. D.; MENDES, K. F.; AQUINO, L. Â. D.; PACHECO, D. D.; RONCHI, C. P. Períodos de interferência de plantas daninhas na cultura do girassol. Bragantia, v. 72, n. 3, p. 255-261, 2013.

SOLANI, N.; DILLE, J. A.; GULDEN, R.; SPRAGUE, C.; ZOLLINGER, R.; MORISHITA, D. W.; LAWRENCE, N. C.; SBATELLA, G. M.; KNISS, A. R.; JHA, P.; SIKKEMA, P. H. Potential yield loss in dry bean crops due to weeds in the United States and Canada. Weed Technology, v. 32, n. 3, p. 342-346, 2018.

SYSTAT. SigmaPlot: version 14.0. San Jose: Systat Inc., 2019.

TEIXEIRA, M. F. F.; BIESDORF, E. M.; PINHEIRO, D. T.; BARROS, T. T. V.; IGLESIAS, E. Interferência de plantas daninhas na qualidade e produtividade do grãode-bico. Revista de Agricultura Neotropical, v. 4, n. 1, p. 69-75, 2017.

THOMAS, W. E.; EVERMAN, W. J.; CLEWIS, S. B.; WILCUT, J. W. Glyphosate-resistant corn interference in glyphosate-resistant cotton. Weed Technology, v. 21, n. 2, p. 372-377, 2007.

VENEGAS, F.; GASPARELLO, A. V.; ALMEIRA, M. P. Determinação de perdas na colheita mecanizada do milho (Zea mays L.) utilizando diferentes regulagens de rotação do cilindro trilhador da colheitadeira. Ensaios $e$ Ciência: Ciências Biológicas, Agrárias e da Saúde, v. 16, n. 1, p. 43-55, 2012. 